\title{
Seismic Discontinuities beneath the southwestern United States from $S$ receiver functions
}

\author{
Olufemi Akanbi ${ }^{1}$ and Aibing $\mathrm{Li}^{1}$ \\ ${ }^{1}$ Department of Earth and Atmospheric Sciences, University of Houston, 4800 Calhoun Rd., \\ Houston, Texas 77204, USA.
}

Corresponding Author: Olufemi Akanbi

Address: 14238 Grace Meadow Lane

Sugarland TX, 77498

USA.

Telephone: 1-832-630-9233

Email: $\quad$ eoakan@yahoo.com

13

14

5

6

7

8

2

3

4




\section{INTRODUCTION}

The region of the Colorado Plateau-Rio Grande Rift-Great Plains (Fig. 1) was assembled in a series of continental building events where the Proterozoic terranes with assemblages of Island arcs, oceanic plateau and marginal basin units were accreted to the continent (Bowring and Karlstrom, 1990; Condie, 1982; Condie and Silverstone, 1999; Frey et al., 2001). The Great Plains (GP) has low relief and has not undergone significant deformation since Precambrian times, and it represents the western edge of the North America craton (Gao et al., 2004). The Colorado Plateau (CP) that has also been tectonically stable since the Precambrian (Morgan et al., 1986) lies to the west at an average elevation of about $1.8 \mathrm{~km}$. The high-standing Plateau is a relatively undeformed crustal block while surrounded by the deformed Rocky Mountains and the Basin and Range Province (BRP) (Foos, 1999). The region between the Colorado Plateau and the Great Plains (Fig. 1) is the Rio Grande Rift (RGR) that consists of a series of north-south trending faulted basins. The area has been a product of series of compressional and extensional forces that have swept this area from Mesozoic time through the Cenozoic and the last $10 \mathrm{Ma}$ (Sheehan et al., 2004).

The southwestern United States has undergone varied tectonic extension along with much of the interior western North America in the past 30 Ma (Baldridge et al., 1991; Olsen et al., 1987; Wilson et al., 2005). The extension has resulted in the creation of the Rio-Grande Rift but has left the Colorado Plateau largely undeformed. The RGR has been formed in at least two stages, the initial stage at about 20-30 $\mathrm{Ma}$ and the later stage at about $10 \mathrm{Ma}$. Increased volcanism in the past $5 \mathrm{Ma}$ has occurred along the Jemez Lineament including the Mount Taylor region and Jemez Mountains. The Jemez lineament lies in the southeastern Colorado Plateau and has been referred to as a transition zone between the CP and RGR. 
Although the Colorado Plateau has been apparently undeformed during the Cenozoic extension in most of the southwestern United States, it has experienced continuous slow uplift between $25 \mathrm{Ma}$ and $5 \mathrm{Ma}$ up to $\sim 800 \mathrm{~m}$, while the main rapid uplift occurred in the last $5 \mathrm{Ma}$

51 with up to $\sim 1100 \mathrm{~m}$ displacement (Sahagian et al., 2002). The margins are marked by major

52 volcanic accumulations that resulted in the bowl-shaped topography of the Plateau (Foos, 1999).

53 Geochemical and geophysical studies indicate that the lithosphere of the plateau has been 54 thermally and chemically eroded at the edge (Crow et al., 2011; Levander et al., 2011; Liu et al., 55 2012; Schmandt and Humphreys, 2010). Several hypotheses have been proposed to explain the 56 general uplift of the plateau, which include large-scale mantle upwelling (Moucha et al., 2009), 57 compositional buoyance in the lithosphere (Karlstrom et al., 2012; Roy et al., 2009), the removal 58 of the Farallon slab and subsequent upwellings (Liu and Gurnis, 2010); and small-scale edge59 driven convection (van Wijk et al., 2010).

Previous seismic experiments and the recent USArray in the southwestern US have 61 resulted in numerous constraints on the crust and mantle structure beneath the Colorado Plateau, 62 Rio Grande Rift, and the Great Plains (Bailey et al., 2012; Bashir et al., 2011; Gao et al., 2004; 63 Gilbert et al., 2007; Kumar et al., 2012; Levander et al., 2011; Levander and Miller, 2012; Li et 64 al., 2007; Liu et al., 2012; Schmandt and Humphreys, 2010; Shen et al., 2013; West et al., 2004a; 65 West et al., 2004b; Wilson et al., 2005). The RGR is characterized by a thin crust and 66 lithosphere with significantly low velocities in the upper mantle to $200-300 \mathrm{~km}$ depth. The 67 Colorado Plateau and the Great Plains have a thick curst $(\sim 45 \mathrm{~km})$ and relatively fast mantle 68 above $200 \mathrm{~km}$.

Despite many studies were conducted from the RISTRA experiment, the lithosphere 70 thickness has not been fully investigated in previous studies. In this study, we processed $\mathrm{S}$ 
71 receiver functions from the RISTRA array and mapped discontinuities in the underneath crust

72 and lithosphere. The high density of the stations allows us to observe sharp depressions of the

73 LAB at the RGR-CP and RGR-GP boundaries. The high-resolution image of crustal and mantle

74 discontinuities sheds light on the dynamic process in the upper mantle beneath the RISTRA array

75 and provides new evidence for small-scale mantle convection that is largely responsible for the 76 recent rifting and uplifting in the area.

\section{METHODOLOGY AND DATA ANALYSIS}

Receiver function methods utilize converted phases of P-to-S or S-to-P from a

80

81

82

83

84

85

86

87

discontinuity and possess a great capability to resolve seismic boundaries in the crust and mantle.

The $S$ receiver function method is powerful in identifying interfaces in the lithosphere and upper mantle because it is free of contamination by multiple reverberations (Li et al., 2007). An Sreceiver function is obtained by deconvolving the $\mathrm{Sv}$ component from $\mathrm{P}$-component using the frequency domain deconvolution approach (Ammon, 1991; Langston, 1979). The method utilizes the equalization of the source and the path effects such that the S-receiver function images the underlying seismic structure beneath individual stations. In the time domain, the ground motion in the $\mathrm{S}$ wave window can be expressed as

$$
\begin{aligned}
& \mathrm{P}(\mathrm{t})=\mathrm{I}(\mathrm{T}) * \mathrm{~S}(\mathrm{t}) * \operatorname{ESv}(\mathrm{t}) \\
& \mathrm{Sv}(\mathrm{t})=\mathrm{I}(\mathrm{t}) * \mathrm{~S}(\mathrm{t}) \ldots \ldots \ldots
\end{aligned}
$$

Where $\mathrm{P}(\mathrm{t})$ and $\mathrm{Sv}(\mathrm{t})$ represent the time series of the $\mathrm{P}$ and $\mathrm{Sv}$ component, respectively; $\mathrm{I}(\mathrm{t})$ is the instrument response; $\mathrm{S}(\mathrm{t})$ is the earthquake source effect; and $\operatorname{ESv}(\mathrm{t})$ is the $\mathrm{S}$ receiver function, consisting of S-to-P conversions from underlying discontinuities. 
In the frequency domain, the $\mathrm{S}$ receiver function is

94

95

96

97

98

99

100

101

102

103

104

105

$$
\begin{aligned}
& \operatorname{ESv}(\omega)=\frac{P(\omega) S v *(\omega)}{F(\omega)} G(\omega) \\
& \mathrm{G}(\omega)=e^{-\frac{\omega^{2}}{4 a^{2}}} \ldots \ldots \ldots \ldots \ldots \ldots
\end{aligned}
$$

Where $\mathrm{Sv}^{*}(\omega)$ represents the complex conjugate of $\mathrm{Sv}(\omega)$; The $\mathrm{G}(\omega)$ in equation (iii) and (iv) represents a Gaussian function that acts as a low pass filter based on the value of "a". A value of 0.4 is used in the study so that the Gaussian function matches the frequency contents of the receiver functions. In addition, "c" in equation (v) represents the water level factor that is used to avoid instability caused by the division of small values. This factor is controlled by signal to noise ratio of the original seismograms and a value of 0.02 was chosen for this research. After calculating $\operatorname{ESv}(\omega)$ from equation (iii), we can obtain the $S$ receiver function, $\operatorname{ESv}(t)$, by applying the inverse Fast Fourier transform.

The dataset used in this study is from the Colorado Plateau-Rio Grande Rift-Great Plains Seismic Transect (LA RISTRA), which consisted of 57 broadband seismometers that were deployed in July 1999 and removed from the field in May 2001 (Fig. 1). The RISTRA seismic array was oriented approximately in NW-SE direction, parallel to the regional Proterozoic accretionary gradient (Bowring and Karlstrom, 1990; Wilson et al., 2005). It extended approximately along a great circle between Lake Powell, Utah and Pecos, Texas with an interstation spacing about $18 \mathrm{~km}$ (Wilson et al., 2005). The experiment was designed to take advantage of the geometry of the geologic basement and back azimuths to prolific teleseismic source zones in the western South America and the northern Pacific. 

and greater than $85^{\circ}$ for SKS wave (Yuan et al., 2006). The distance range for S-P conversions 117 depends mainly on the depth of the discontinuity and the conversions do not occur over critical 118 angles. In this study, we requested all teleseismic events with $\mathrm{Mb}>5.8$ in a distance range of $11960^{\circ}-110^{\circ}$ from the IRIS data management center (Fig. 2) for both S and SKS receiver function 120 analysis. The number of events at each station varies from 30 to 55 with an average of 45 events 121 per station.

We filtered three-component seismograms for selected events with a frequency band of $1230.05-0.12 \mathrm{~Hz}$ to remove high frequency noises and kept the waveforms with high signal-to124 noise ratios for $\mathrm{S}$ and SKS phases. The selected seismograms were rotated from Z, N, and E 125 components to $\mathrm{P}, \mathrm{SV}$, and $\mathrm{SH}$ components to separate the $\mathrm{S}$ wave and its converted $\mathrm{P}$ wave 126 signals. Then individual receiver functions are obtained using the method above. Time is 127 reversed on $\mathrm{S}$ receiver functions so that $\mathrm{Sp}$ converted phases are at a positive time because they 128 actually arrived earlier than the direct $\mathrm{S}$ or SKS waves. The amplitude of $\mathrm{S}$ receiver function is 129 also flipped relative to zero in order to be consistent with $\mathrm{P}$ receiver functions on which a 130 positive converted phase corresponds to an interface with a positive velocity gradient. One 131 criterion we applied to select useful receiver function is a clear $\mathrm{S}$ to $\mathrm{P}$ converted phase from the 132 Moho. Individual receiver functions are inspected carefully and obvious bad traces are removed. Individual receiver functions are stacked by ray piercing point to improve the signal-to134 noise ratio of the $\mathrm{S}$ to $\mathrm{P}$ converted phases. The piercing points of S-to-P converted phases for 135 both $\mathrm{S}$ and SKS phase are calculated from the IASP91 model (Kennett and Engdahl, 1991) at a 136 conversion depth of $90 \mathrm{~km}$ (Fig. 3). The conversion points of Sp phases could be $100 \mathrm{~km}$ away 137 from the associated station, which makes it necessary to stack receiver functions by binning the 
138 piercing points instead of by station. 54 bins are produced with the bin dimension represented by 139 consecutive parallel lines covering a distance of $\sim 44 \mathrm{~km}$ (Fig. 3); and the center of each bin 140 coincides with the station location. The width of each bin is designed to contain at least 10 141 piercing points. We used a bin width of $44 \mathrm{~km}$, which provides a coherent image of the stacked 142 receiver functions, after trying several values $(11,33,44$, and $55 \mathrm{~km})$. The number of piercing 143 points within each bin varies from 15 to 25 . Given that the station spacing is about $18 \mathrm{~km}$, the 144 neighboring two bins overlap about $26 \mathrm{~km}$ along the station profile.

Both S and SKS receiver functions are stacked together provided their piercing points are

146 located in the same bin. Moveout for distance is corrected with a reference ray parameter 6.4 147 s/deg using the IASP91 model (Kennett and Engdahl, 1991) as performed by Li et al. (2007).

148 The moveout value represents the time difference between the travel time difference of the $\mathrm{S}$ 149 phase and Sp phase for a given ray with respect to the travel time difference of the reference ray. 150 The moveout correction aligns all responses from different ray paths from the same discontinuity 151 at the same time. Therefore, stacking receiver functions with the moveout corrections improves 152 the amplitude of the converted phase while suppresses random noises that are canceled out by 153 destructive interferences. The stacked receiver functions are migrated from time to depth domain 154 based on the IASP91 model (Kennett and Engdahl, 1991). The migration produces a depth image 155 of the earth's internal discontinuities and helps to better view the subsurface structure.

\section{RESULTS OF RECEIVER FUNCTION IMAGING}

We generated $\mathrm{S}$ receiver functions from $\mathrm{S}$ and $\mathrm{SKS}$ waveform data for 54 stations of the 
16060 at one station, but many were discarded due to large noise or lack of clear S to P conversion

161 from the Moho. Fig. 4 displays S receiver functions in four bins corresponding to four stations

162 that are located in the GP, RGR, CP-RGR boundary and CP, respectively. A summation trace is

163 produced for each bin by stacking individual S and SKS receiver functions whose piercing points

164 are within the same bin. It is noticeable that the energy level after $20 \mathrm{~s}$ is significantly reduced on

165 the summed traces, suggesting that much of that energy on individual $\mathrm{S}$ receiver functions is 166 caused by random noise. Therefore, we only focus on coherent signals across the profile, which

167 are presumably from true structures. The stack traces at all stations (Fig. 5) are migrated to depth

168 using the IASP91 model (Kennett and Engdahl, 1991) and plotted with color-coded amplitude 169 across the RISTRA profile (Fig. 6a).

\section{$171 \quad 3.1$ The Moho discontinuity}

The most obvious and coherent converted phases are around 4-6 s beneath all the

173 stations, which are the S to $\mathrm{P}$ conversions from the Moho. The Moho depth varies from 30 to 40

$174 \mathrm{~km}$ beneath the RGR and from 35 to $45 \mathrm{~km}$ beneath the Great Plains and the Colorado Plateau.

175 The Moho beneath the Great Plains is imaged by a sharp Sp conversion from stations TX01-

176 NM14 with a depth of about $40 \mathrm{~km}$. A slightly deeper Moho at $45 \mathrm{~km}$ is observed beneath

177 stations NM16-NM18, corresponding to the Ruidoso volcanic field known as the Pajarito

178 Mountain (Bowsher, 1991; Roberts et al., 1991). Similarly, the Moho depth at Mount Taylor, a

179 major volcanic field of the Jemez lineament is about $45 \mathrm{~km}$ beneath stations NM32-NM34. The

180 Moho depth under stations NM20-NM32 ranges from $30-40 \mathrm{~km}$, roughly coinciding with the

181 surface morphology of the rift. The Moho beneath the Colorado Plateau west of station NM34 
ranges from 40-45 km. The variations of the Moho depth imaged from $\mathrm{S}$ receiver functions from this study are largely consistent with those constrained from P receiver functions (Wilson et al., 2005). In addition, other $\mathrm{P}$ and $\mathrm{S}$ receiver function studies also show that the Moho in the $\mathrm{CP}$ further away from the RGR boundary is at 40-45 km (Bashir et al., 2011; Gilbert et al., 2007; Hopper et al., 2014; Lekic and Fischer, 2014). The agreement in the Moho depth between S and $\mathrm{P}$ receiver functions gives us confidence about the $\mathrm{S}$ receiver function image for upper mantle discontinuities beneath the RISTRA array.

\subsection{Discontinuities in the upper mantle}

Several coherent Sp converted phases are imaged in the upper mantle beneath the RISTRA profile. The first one is a negative phase at 8-12 s (blue line in Fig. 5 and Fig. 6a) beneath all three provinces. This phase has a sharp peak and large amplitude beneath the RGR and the interior of the CP and GP, but is broad and weak at the boundaries of RGR-CP and RGRGP. This phase shares a similar variation pattern along the profile as the Moho converted phase; indicate that it could be partially attributed to the side-lobe of the strong Moho conversion. However, the side lobe of the Moho conversion is usually much weaker (Lew, 2010) than some observed phases in Fig. 5, suggesting possible contributions from a seismic discontinuity with a negative velocity gradient. This is especially true beneath the RGR, where the phase at $\sim 10 \mathrm{~s}$ has a large amplitude and no other coherent phase is imaged in the upper mantle. It is possible that the Sp phase from the lithosphere-asthenosphere boundary beneath the RGR coincides with the side lobe of the Moho conversion. If so, the LAB beneath the RGR is mapped at the depth of $\sim 80 \mathrm{~km}$. Beneath the interior of CP and GP away from the RGR, if this phase is not fully due to the Moho side lobe but also correlates with a seismic discontinuity, the corresponding depth of 
205 the discontinuity is about $80-90 \mathrm{~km}$ and $\sim 70 \mathrm{~km}$, respectively. This discontinuity is too shallow 206 to be the LAB for these two provinces. We therefore interpret it as the mid-lithosphere 207 discontinuity that might be caused by anisotropy variation within the lithosphere as found in 208 other stable continental region (Rychert and Shearer, 2009; Ford et al., 2010).

Another weak but consistent negative phase is observed at $\sim 16 \mathrm{~s}$ beneath the CP-RGR 210 boundary (station 34-41) and gradually deepens to $\sim 22 \mathrm{~s}$ towards the interior of the CP (Fig. 5).

211 This phase is also present at the RGR-GP boundary (station 08-14) at $\sim 12 \mathrm{~s}$. We interpret that 212 this weak and later phase beneath the $\mathrm{CP}$ and GP as $\mathrm{S}$ to $\mathrm{P}$ conversions from the lithosphere213 asthenosphere boundary. The depth of the LAB is $\sim 100 \mathrm{~km}$ beneath the Great Plains and at 214 120-180 km beneath the Colorado Plateau. The LAB depth increases sharply from $\sim 80 \mathrm{~km}$ 215 beneath the RGR to $120 \mathrm{~km}$ beneath the $\mathrm{CP}$ and $100 \mathrm{~km}$ beneath the GP in less than $50 \mathrm{~km}$ 216 distance on the surface, evidence for sudden variations of the lithosphere structure across the 217 boundaries of tectonic provinces.

219 Plateau observed in this study is similar to previous results from receiver function images using 220 the USArray data (Levander et al., 2011; Levander and Miller, 2012; Kumar et al., 2012; Kind et 221 al., 2012; Lekic and Fischer, 2014), while the absolute lithosphere thickness beneath the CP is 222 about 40-60 km thicker than the previous values, which could be caused by different frequencies 223 used in the data. In addition, the sharp increase of the lithosphere thickness at the RGR-CP and 224 the RGR-GP boundary is a unique feature from this dataset owing to the much higher station 225 density. 
We also observe a strong, coherent positive phase at $\sim 32 \mathrm{~s}$ and a negative phase at $\sim 37 \mathrm{~s}$

227 at stations of 41-49 in the Colorado Plateau, corresponding to a discontinuity at the depth of

$228 \sim 250 \mathrm{~km}$ and $\sim 300 \mathrm{~km}$, respectively. These discontinuities must be a local feature as no similar

229 phases appear in other places of the profile. Seismic velocity increases across the shallower

230 discontinuity but decreases across the deeper one, which can be explained as a segment of the

231 eroded lithosphere whose velocity is higher than the surrounding asthenosphere.

\section{4. DISCUSSION}

233 4.1 Uncertainties of the depths of discontinuities

The depths of imaged discontinuities from $\mathrm{S}$ receiver functions depend on the accuracy in 235 picking the peak time of an S-P phase, the velocity model used in depth migration, and the 236 dominant frequency in the data. The picking error is related to the amplitude and sharpness of 237 the converted phase that reflects the velocity gradient across the discontinuity. A larger velocity 238 gradient across a boundary tends to produce a sharper conversion (Kind et al., 2012). The errors 239 of our phase picks range from $0.25 \mathrm{~s}$ to $0.5 \mathrm{~s}$, corresponding to $2-4 \mathrm{~km}$ in depth. The velocity 240 model that we used in depth migration is a global reference model, IASP91, which is faster than 241 the regional velocity model beneath the RGR and comparable with the model beneath the CP 242 (Liu et al., 2011). An average 5\% slower model would map the Moho and LAB about $2 \mathrm{~km}$ and $2435 \mathrm{~km}$ shallower, respectively. If this correction is applied to the RGR area, the LAB variation 244 across the RGR-CP boundary will be even more significant.

These uncertainties from the picking errors and velocity model together cannot explain 246 the difference between the 160-180 km thick lithosphere imaged beneath the Colorado Plateau 247 from this study and $\sim 120 \mathrm{~km}$ found in previous studies (Levander and Miller, 2012; Lekic and 248 Fischer, 2014). We suspect that the difference in dominant frequencies among the studies $(0.2$ 
$249 \mathrm{~Hz}$ in (Levander and Miller, 2012); 0.03-0.25 Hz in (Lekic and Fischer, 2014); and 0.05-0.12 Hz

250 in our study) is probably a key reason for the discrepancy of the LAB depth. Kind et al. (2012)

251 have shown that $S$ receiver functions of different frequency have varying resolution for a 252 smoothing discontinuity with gradational velocity variation. S receiver functions at a period of $253 \sim 13 \mathrm{~s}$ can still image a gradational velocity drop $(\sim 0.5 \mathrm{~km} / \mathrm{s}$ over $100 \mathrm{~km}$ depth$)$, which cannot be 254 detected by $\mathrm{S}$ receiver functions at shorter periods (4 $\mathrm{s}$ and $7 \mathrm{~s}$ ). The discrepancy between our 255 results and previous ones indicates that the LAB beneath the CP has varying velocity gradients, a 256 sharper gradient above $\sim 140 \mathrm{~km}$, which is observed from short period data (Levander and Miller, 257 2012; Lekic and Fischer, 2014), and a smoother gradient underneath, which is imaged from long 258 period data (this study). Such velocity gradient variation with depth is also consistent with 259 velocity models constrained from surface waves (West et al., 2004; Liu et al., 2011).

261 4.2 Lithosphere extension and mantle upwelling beneath the RGR

The estimated lithospheric depth beneath the Rio Grande Rift ranges from 70 to $80 \mathrm{~km}$, much thinner than beneath the adjacent Colorado Plateau $(120-180 \mathrm{~km})$ and the Great Plains $264(\sim 100 \mathrm{~km})$. The observation of an elevated LAB is consistent with many previous studies in the 265 RGR. Lithosphere thinning and asthenosphere upwarp beneath the RGR has been evident from 266 P wave residual and gravity modeling (Parker et al., 1984), from chemical and isotopic 267 constraints (Perry et al., 1988), and from body and surface wave tomography models using data 268 from the RISTRA experiment and the USArray (Gao et al., 2004; West et al., 2004; Levander et 269 al., 2011; Liu et al., 2012; Schmandt and Humphreys, 2010; Shen et al., 2013). Besides the 270 shallow LAB, asthenosphere upwelling beneath the RGR is evident by the strong Sp phases, 
271 which indicates a sharp velocity drop across the LAB and a presumably hot asthenosphere.

272 Tomography models have indeed imaged significantly low velocity in the upper mantle of RGR

273 (Gao et al., 2004; West et al., 2004; Liu et al., 2011).

We estimate a stretching factor of 1.25-1.43 under the RGR assuming a uniform 275 extension of the lithosphere (McKenzie, 1978) and an initial lithosphere thickness of $100 \mathrm{~km}$

276 although the actual lithosphere stretching is probably depth dependent and more complicated

277 than McKenzie's model. Hot asthenosphere upwelling, which is a passive consequence of 278 lithosphere stretching in McKenzie's rifting model, is probably produced by the removal of flat 279 Farallon slab and enhanced by edge-driven convection (Liu and Gurnis, 2010; van Wijk et al., 280 2010) and is likely the cause of lithosphere extension in the Rio Grande Rift.

The lithospheric thickness varies from $80 \mathrm{~km}$ beneath the RGR to $100 \mathrm{~km}$ beneath the GP 284 and 120-180 $\mathrm{km}$ beneath the $\mathrm{CP}$. The LAB variation imaged from $\mathrm{S}$ receiver functions is 285 consistent with a negative velocity gradient beneath the RISTRA in the S velocity model by 286 West et al. (2004) (Fig. 6b). An interesting observation is the sharp lithosphere step at the RGR287 CP boundary, where the LAB deepens by $\sim 40 \mathrm{~km}$ in less than $50 \mathrm{~km}$ horizontal distance. This 288 lithosphere step, which is at a scale smaller than the station spacing in the USArray network, was 289 not revealed in regional LAB maps from the USArray data (Kumar et al., 2012; Levander et al., 290 2011; Levander and Miller, 2012; Lekic and Fischer, 2014). The lithosphere step at the RGR-CP 291 boundary corresponds to the rapid change of surface elevation and probably marks the boundary 292 of the two tectonic provinces at depth. 
A sharp lithosphere thickness change can produce edge-driven convection in the upper 294 mantle as simulated by van Wijk et al. (2010). Our observation suggested such a step of the 295 LAB indeed exists at the RGR-CP and RGR-GP boundaries, which would promote small-scale 296 mantle convection, upwelling beneath the RGR and downwelling at its boundary, as shown in

297 the schematic model in Figure 7. Our image of two local discontinuities at $\sim 250 \mathrm{~km}$ and $\sim 300$ $298 \mathrm{~km}$ depth beneath the southeastern CP boundary could be the top and base of the removed 299 lithosphere, a consequence of the small-scale mantle convection.

Geophysical, geochemical and geological evidence all support that the extension and 301 uplift in southwestern US are driven by mantle processes (Crow et al., 2011; Karlstrom et al., 302 2008; Karlstrom et al., 2012; Levander et al., 2011; Schmandt and Humphreys, 2010). Multiple 303 mechanisms must have played important roles for regional tectonic activities at different times. 304 Strong asthenosphere upwelling was expected following the descent of Farallon slab and largely 305 responsible for the extension and widespread magmatism in the RGR at 30-40 Ma. The 306 extension in the RGR significantly thinned the lithosphere while the strong lithosphere beneath 307 the CP remains largely undeformed. The lithosphere step then formed at the RGR-CP boundary, 308 as imaged in this study, and invoked edge-driven convection, which causes upwelling beneath 309 the CP and RGR and downwelling at the RGR-CP boundary as simulated by numerical modeling 310 (van Wijk et al., 2010). The edge-driven, small-scale mantle convection is likely the current 311 mechanism that is responsible for recent uplift and magmatism in the Rio Grande Rift and the 312 Colorado Plateau. 
316 S receiver functions along the RISTRA transect clearly image the Moho and LAB. A 317 shallower Moho and LAB beneath the RGR than the adjacent CP and GP indicate lithosphere 318 extension and asthenosphere upwarp beneath the rift. The lithosphere under the CP deepens from $319 \sim 120 \mathrm{~km}$ at the RGR-CP boundary to $\sim 180 \mathrm{~km}$ towards the northwestern interior. An 320 anomalous lithosphere step of $\sim 40 \mathrm{~km}$ is observed at RGR-CP boundary, providing evidence for 321 edge-driven convection. Two local discontinuities at $\sim 250 \mathrm{~km}$ and $\sim 300 \mathrm{~km}$ beneath the 322 southeastern CP probably image the top and bottom boundary of the eroded lithosphere. The 323 LAB variation along the RISTRA provides further evidence for small-scale, edge-driven mantle 324 convection, which is likely the dominant mechanism for recent magmatism and uplift in the Rio 325 Grande Rift and Colorado Plateau region.

\section{ACKNOWLEDGMENTS}

The authors thank the IRIS Data management center where all of the data used in this 329 research were downloaded. In addition, we thank all the RISTRA team for conducting this 330 experiment. Two anonymous reviewers provided constructive comments that help to improve 331 this paper. This research was supported by a NSF grant EAR-0645503. 


\section{REFERENCES}

Abt, D. L., Fischer, K.M., French, S.W., Ford, H.A., Yuan, H., Romanowicz, B., 2010. North American lithosphere discontinuity structure imaged by Ps and Sp receiver functions. Journal of Geophysical Research 115, B09301, doi:10.1029/2009JB006914.

Ammon, C.J., 1991. The isolation of receiver effects from teleseismic P- wave -forms. Bulletin Seismological Society of America 81, 2504-2510.

Bailey, I.W., Miller, M.S., Liu, K.J., Levander, A., 2012. V-S and density structure beneath the Colorado Plateau constrained by gravity anomalies and joint inversions of receiver function and phase velocity data. Journal of Geophysical Research 117, B2, doi:10.1029/2011JB008522.

Baldridge, W.S., Perry, F.V., Vaniman, D.T., Nealey, L.D., Leavy, B.D., Laughlin, A.W., Kyle, P.R., Bartov, Steinitz, Y.G., Gladney, E.S., 1991. Middle to Late Cenozoic magmatism of the Southern Colorado Plateau and Central Rio Grande Rift (New Mexico and Arizona, USA): A model for Continental rifting. Tectonophysics 197, 327-354.

Bashir, L., Gao, S.S., Liu, K.H., Mickus, K., 2011. Crustal structure and evolution beneath the Colorado Plateau and the southern Basin and Range Province. Result of receiver function and gravity studies, Geochemistry, Geophysics. Geosystem 12, Q06008.

Beghoul, N., Barazangi, M., Isacks, B.L., 1993. Lithospheric structure of Tibet and Western North America. Mechanism of uplift and a comparative study: Journal of Geophysical Research 98, 1997-2016. 
Berglund, H.T., Sheehan, A.F., Murray, M.H., Roy, M., Lowry, A.R., Nerem, R.S., Blume, R., 2012. Distributed deformation across the Rio Grande Rift, Great Plains and Colorado Plateau. Geology 40 (1), 23-26, doi: 10.1130/G32418.1.

Bowring, S.A., Karlstrom, K.E., 1990. Growth stabilization and reactivation of Proterozoic lithosphere in Southwestern United States. Geology 19 (12), 1203-1206.

Bowsher, A.L., 1991. Some effects of Precambrian basement on the development of Sacramento Mountains, in Geology of the Sierra Blanca, Socorro, New Mexico, New Mexico Geological Society $42^{\text {nd }}$ Annual Field Conference: Socorro, New Mexico, 81-89.

Condie, K.C., Silverstone, J., 1999. The crust of Colorado Plateau: New view of an old arc. Journal of Geology 107, 387-397.

Condie, K.C., 1982. Plate tectonics model for Proterozoic continental accretion in the Southwestern United States. Geology 10, 37-42.

Crow, R., Karlstrom, K., Asmerom, Y., Schmandt, B., Polyak, V., Andrew DuFrane, S., 2011. Shrinking of the Colorado Plateau via lithospheric mantle erosion: Evidence from Nd and $\mathrm{Sr}$ isotopes and geochronology of Neogene. Geology 39 (1), 27-30, doi: 10.1130/G31611.1.

Fisher, M., Ford, H.A., Abt, D.L., Rychert, C.A., 2010. The lithosphere-asthenosphere boundary. Annual Review Earth Planetary Science 38, 549-573.

Foos, A., 1999. Geology of the Colorado Plateau, Nature 1-6.

Ford, H.A, Fischer, K.M., Abt, D.L., Rychert, C.A., Elkins-Tanton, L.T., 2010. The lithosphereasthenosphere boundary and cratonic lithospheric layering beneath Australia from Sp 
wave imaging. Earth and planetary Science letters 300, 299-310, doi: 10.1016/j.eps1.2010.10.007.

Frey, B.A., Condie, K.C., Kerrich, R., 2001. The Iron king volcanic: A remnant of an oceanic Plateau accreted to southwestern Laurentia $1.7 \mathrm{Ga}$. Geological Society of America Abstract Programs 33 (5), 24.

Gao, W.S., Grand, W.S., Baldridge, D., Wilson, D., West, M., Ni, J., Aster, R., 2004. Upper mantle convection beneath the Central Rio Grande Rift imaged by $\mathrm{P}$ and $\mathrm{S}$ wave tomography. Journal of Geophysical Research 109, B03305, doi:10.101029/2003JB002743.

Gilbert, H., Velasco, A., Zandt, G., 2007. Preservation of Proterozoic terrane boundaries within the Colorado Plateau and implications for its tectonic evolution. Earth and Planetary Science Letters 258, 237-248, doi: 10.1016/j.epsl.2007.03.034.

Gilbert, H., 2012. Crustal structure and signatures of recent tectonism as influenced by ancient terranes in the western United States. Geosphere 8 (1), 141-157, doi: 10.1130/GES00720.1.

Hopper, E., Ford, H.E., Fischer, K.M., Lekic, V., and Fouch, M.J., 2014. The lithosphereasthenosphere boundary and the tectonic and magmatic history of the northwestern United States. Earth and Planetary Science Letters 402, 69-81. doi:10.1016/j.epsl.2013.12.016.

Humphreys, E.D., Dueker, K.G., 1994. Western US upper mantle structure. Journal of Geophysical Research 99, 9615-9634. Incorporated Research Institutions for Seismology (IRIS) Website. http://www.iris.edu (December 2013). 
402

403

404

405

406

407

408

409

410

411

412

413

414

415

416

Jones, C.H., Phinney, R.A., 1998. Seismic structure of the lithosphere from teleseismic converted arrivals of small arrays in the Southern Sierra Nevada and vicinity, California. Journal of Geophysical Research 103, 10065-10090.

Karlstrom, K.E., Crow, R., Crossey, L.J., Coblentz, D., and Van Wijk, J., 2008. Model for tectonically driven incision of the younger than 6 Ma Grand Canyon. Geology 36, 835838.

Karlstrom, K.E., Coblentz, D., Dueker, K., Ouimet, W., Kirby, E., Van Wijk, J., Schmandt, B., Kelly, S., Lazear, G., Crossey, L.J., Crow, R., Aslan, A., Darling, A., Aster, R., MacCarthy, J., Hansen, S.M., Stachnik, J., Stockli, D.F., Garcia, R.V., Hoffman, M., McKeon, R., Feldman, J., Heizler, M., Donahue, M.S., the CREST Working Group, 2012. Mantle-driven dynamic uplift of the Rocky Mountains and Colorado Plateau and its surface response: Toward a unified hypothesis. Lithosphere 4 (1), 3-22, doi:10.11330/L150.1.

Kennett, B.L.N., Engdahl, E.R., 1991. Travel times for global earthquake location and phase association: Geophysical Journal International 105, 429-465.

Kind, R., Yuan, X., Kumar, P., 2012. Seismic receiver functions and the lithosphereasthenosphere boundary. Tectonophysics 536-537, 25-43, doi: 10.1016/j.tecto.2012.03.005.

Kumar, P., X. Yuan, Kind, R., Kosarev, G., 2005b. The lithosphere-asthenosphere boundary in the Northwest Atlantic region: Earth Planetary Science Letters 236, 249-257. 
417 Kumar, P., Yuan, X., Kind, R., and Mechie, J., 2012. The lithosphere-asthenosphere boundary observed with USArray receiver functions. Solid Earth 3, 149-159, doi: 10.5194/se-3149-2012.

420

421

422

423

424

425

426

427

428

429

430

431

432

433

434

435

436

437

Kumar, P., Kind, R., Yuan, X., Mechie, J., 2012. USArray receiver function images of the lithosphere-asthenosphere boundary. Seismological Research Letters 83, 487-492. doi:10.1785/gssrl.83.3.487.

Langston, C.A., 1979. Structure under Mount Rainer, Washington inferred from teleseismic body-waves. Journal of Geophysical Research 84, 4749-4762.

Lekic, V., and Fischer, K.M., 2014.Contrasting lithospheric signatures across the western United States revealed by Sp receiver functions. Earth and Planetary Science Letters 402, 90-98. doi: 10.1016/j.epsl.2013.11.026.

Levander, A., Schmandt, B., Miller, M.S., Liu, K., Karlstrom, K.E., Crow, R.S., Lee, C.T.A., Humphreys, E.D., 2011. Continuing Colorado plateau uplift by delamination-style convective lithospheric downwelling. Nature 472, 461-466, doi: 10.1038/nature10001.

Levander, A., Miller, M.S., 2012. Evolutionary aspect of lithosphere discontinuity structure in the Western U.S. Geochemistry Geophysics Geosystems, doi: 10.1029/2012GC004056, in press.

Lew, K. W., 2010. The lithospheric structure beneath the Tanzanian craton from S receiver functions, MSc thesis in geophysics, University of Houston, USA, 60p.

Li, A., Burke, K., 2006. Upper mantle structure of Southern Africa from Rayleigh wave tomography. Journal of Geophysical Research 111.B10303. 
438 Li, X., Yuan, X., Kind, R., 2007. The lithosphere-asthenosphere boundary beneath the Western United States. Geophysical Journal International 170, 700-710.

440 Liu, L., Gurnis, M., 2010. Dynamic subsidence and uplift of the Colorado Plateau, Geology 38

441 (7), 663-666, doi: 10.1130/G30624.1.

442 Liu, K., Levander, A., Niu, F., Miller, M.S., 2011. Imaging crustal and upper mantle structure 443

444 beneath Colorado Plateau using finite frequency Rayleigh wave tomography. Geochem. Geophys. Geosyst., 12, Q07001, doi:10.1029/2011GC003611.

445

446 Liu, K., Levander, A., Zhai, Y., Porritt, R. W., Allen, R. M., 2012. Asthenospheric flow and lithospheric evolution near the Mendocino triple junction. Earth and Planetary Science Letters 323-324, 60-71.

449

Ma, S., 2010. Mapping the lithosphere structure beneath Southern Africa from S receiver functions, MSc thesis in geophysics, University of Houston, USA, 63p.

McKenzie, D.,1978. Some remarks on the development of sedimentary basins. Earth and Planetary Science Letters 40 (1), 25-32.

453 Morgan, P., Seager, W.R., Golombek, M.P., 1986. Cenozoic uplift and tectonic evolution of the 454 Rio Grande Rift. Journal of Geophysical Research 91, 6263-6276.

455 Moucha, R., Forte, A.M., Rowley, D.B., Mitrovica, J.X., Simmons, N.A., Grand, S.P., 2009. 456 Deep mantle forces and the uplift of the Colorado Plateau. Geophysical Research Letters 36, L 19310, doi: 10.1029/2009GL039778. 
458 Olsen, K.H., Baldridge, W.S., Callender, J.F., 1987. Rio Grande Rift: An overview. $459 \quad$ Technophysics 143, 119-139.

460 Parker, E.C., Davis, P.M., Evans,J.R., Iyer, H.M., Olsen, K.H., 1984. Upwarp of anomalous asthenosphere beneath the Rio Grande rift. Nature 312, 354-356.

462 463

464

465

466

467

468

469

470

471

472

473

474

475

476

Perry, F.V, Baldrigde, W.S., DePaolo, D.J., 1988. Chemical and isotopic evidence for lithospheric thinning beneath Rio Grande Rift. Nature 332, 432-434, doi: $10.1038 / 332432 \mathrm{a} 0$.

Reid, M.R., Bouchet, R.A., Blichert-Toft, J., Levander, A., Liu, K., Miller, M.S., Ramos, F.C., 2012. Melting under the Colorado Plateau. Geology 40 (5), 387-390, doi: 10.1130/G32619.1

Roberts, D., Adams, D., Keller, G.R., 1991. A geophysical analysis of crustal structure in the Ruidoso area, in Geology of the Sierra Blanca, Socorro, New Mexico, New Mexico Geological Society 42 ${ }^{\text {nd }}$ Annual Field Conference: Socorro, New Mexico, 191-197.

Roy, M., Jordan, T.H., Pederson, J.L., 2009. Colorado Plateau magmatism and uplift by warming and heterogeneous lithosphere. Nature 459, 978-982, doi: 10.1038/nature08052.

Rychert, C.A., Shearer, P.M., 2009. A global view of lithosphere-asthenosphere boundary. Lithosphere. Science 324, 495-498. doi: 10.1126/science.1169754.

Sahagian, D., Proussevitch, A., Carlson, W., 2002. Timing of Colorado Plateau uplift. Initial constraints from vesicular basalt-derived paleoelevations. Geology 30 (9), 807-810. 
477 Schmandt, B., Humphreys, E.D., 2010. Complex subduction and small-scale convection revealed

478

479

480

481

482

483

484

485

486

487

488

489

490

491

492

493

494

495

496

497 by body-wave tomography of the western U.S. upper mantle. Earth and Planetary Science Letters doi: 10.1016/j.eps1.2010.06.047.

Sheehan, A.F., Abers, G.A., Jones, C.H., Lerner-Lam, A.L., 1995. Crustal thickness variations across the Colorado Rocky Mountains from teleseismic receiver function. Journal of Geophysical Research 100, 20391-20404.

Sheehan, J.R., Doll, W.E., Mandell, W., 2004. Comparison of MASW and Refraction Tomography: Extended Abstract presented at the 2004 Annual meeting of the symposium on the application of Geophysics to Engineering and Environmental problems; Colorado Springs, Co., Feb. 22-26, 2004.

Shen, W., Ritzwoller, M.H., Schulte-Pelkum, V., 2013. A 3-D model of the crust and uppermost mantle beneath the Central and Western US by joint inversion of receiver functions and surface wave dispersion. Journal of Geophysical Research Solid earth 118, 1-15, doi:10.1029/2012JB009602.

Sine, C.R., Wilson, D., Gao, W., Grand, S.P, Aster, R., Ni, J., Baldridge, W.S., 2008. Mantle structure beneath the western edge of the Colorado Plateau. Geophysical Research Letters 35, L10303, 1-5, doi: 10.1029/2008GL033391.

Suzanne, Y.O., Griffin, W.L., 2010. The continental lithosphere-asthenosphere boundary: Can we sample it?. Lithosphere doi:10.1016/j.lithos.2010.03.016.

van Wijk, J.W., Baldrigde, W.S, Van Hunen, J., Goes, S., Aster, R., Coblentz, D.D., Grand, S.P., Ni, J., 2010. Small scale convection at the edge of the Colorado Plateau: Implications for 
topography, magmatism, and evolution of Proterozoic lithosphere. Geology 38, 611-614, doi: 10.1130/G31031.1.

West, M.J., Baldridge, W.S., Wilson, D., Aster, R., Gao, W., Grand, S., 2004. Crust and upper mantle shear wave structure of Southwest United States: Implication for rifting and support for high elevation. Journal of Geophysical Research 109, B03309, doi: 10.1029/2003JB002575.

West, M.J., Gao, W., Grand, S., 2004. A simple approach to the joint inversion of seismic body and surface wave applied to the Southwest United States. Geophysical Research Letters 31, L15615, doi: 10.1029/2004GL020373.

Wilson, D., Aster, R., the RISTRA Group, 2003. Imaging crust and upper mantle seismic structure in the Southwestern United States using teleseismic receiver functions. Leading Edge 22, 232-237.

Wilson, D., Aster, R., 2005. Seismic imaging of the Crust and upper mantle using regularized joint receiver functions, frequency-wave number filtering and multimode Kirchhoff migration. Journal of Geophysical Research B05305, doi:1029/2004JB003430.

Wilson, D., Aster, R., Ni, J., Grand, S., West, M., Gao, W., Baldridge, W.S., Semken, S., 2005. Imaging the seismic structure of the crust and upper mantle beneath the Great Plains, Rio Grande Rift and Colorado Plateau using receiver functions. Journal of Geophysical Research 110, B05306, doi:10.1029/2004JB003492.

Yuan, X., Kind, R., Li, X., Wang, R., 2006. The S receiver functions: synthetics and data example. Journal of Geophysical International 165, 555-564. 
519 Zandt, G., Meyer, S.C., Wallace, T.C., 1995. Crust and mantle structure across the Basin and 520 Range-Colorado Plateau boundary at 370N latitude and implications for Cenozoic extensional mechanism. Journal of Geophysical Research 10, 10529-10548. example. Journal of Geophysical International 165, 555-564. 


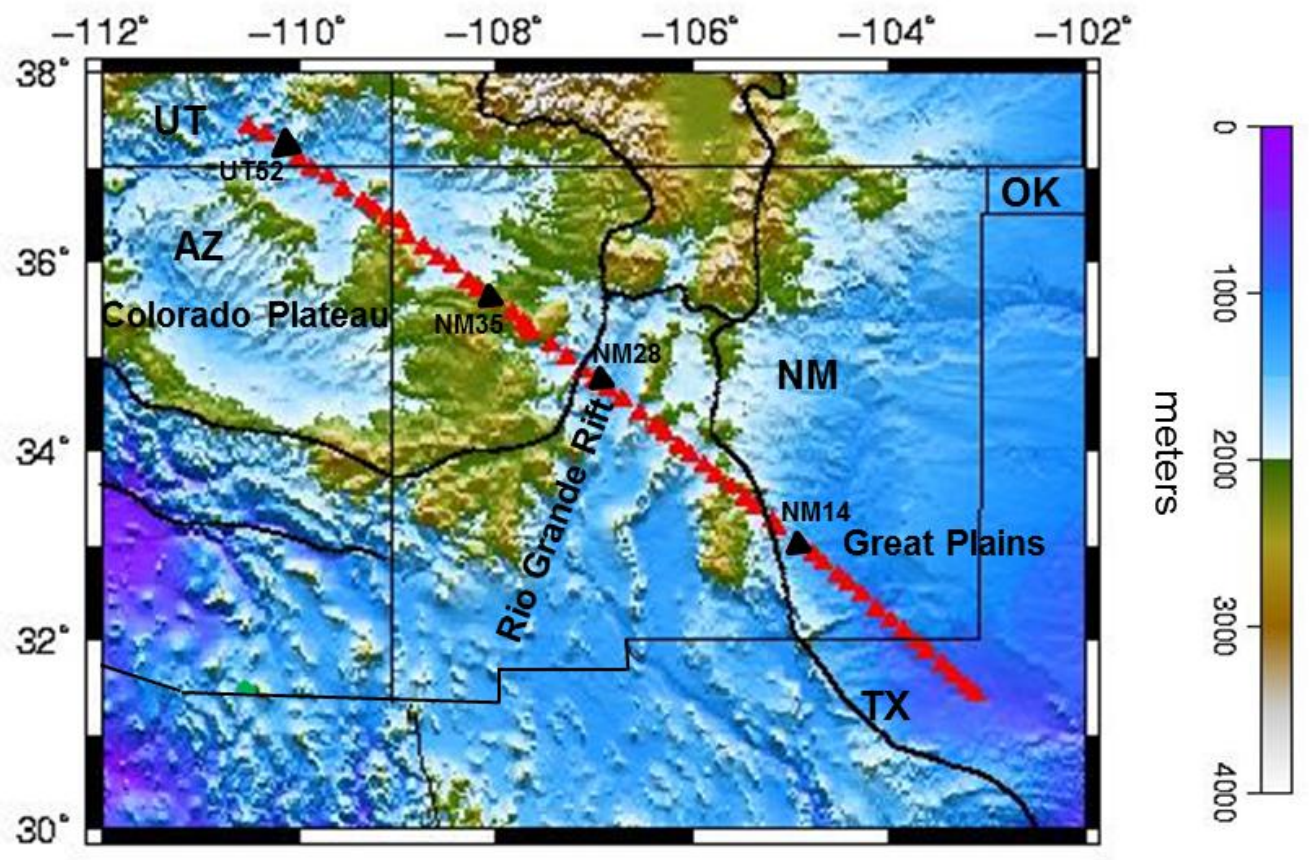

Figure 1. Map of the RISTRA array and topography of the study area. Red triangles represent the locations of 54 stations; black triangles are stations shown in Figure 4. 


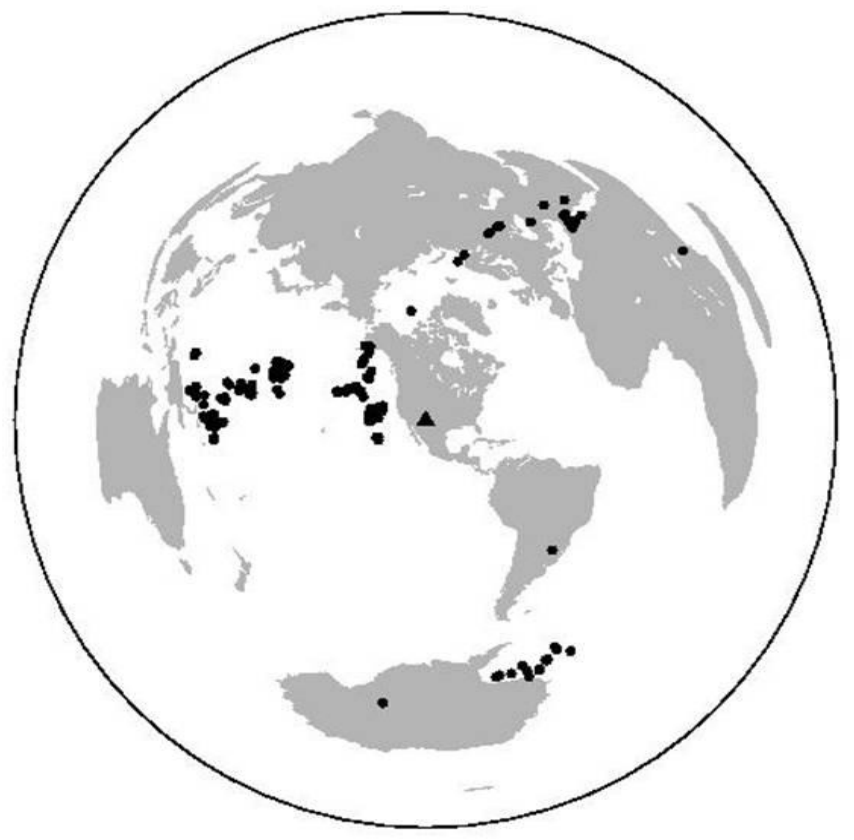

Figure 2. The distribution of used earthquakes (black dots) with $\mathrm{Mb}>5.8$ recorded during the RISTRA deployment. The study area is represented by a black triangle as the center of the projection. 


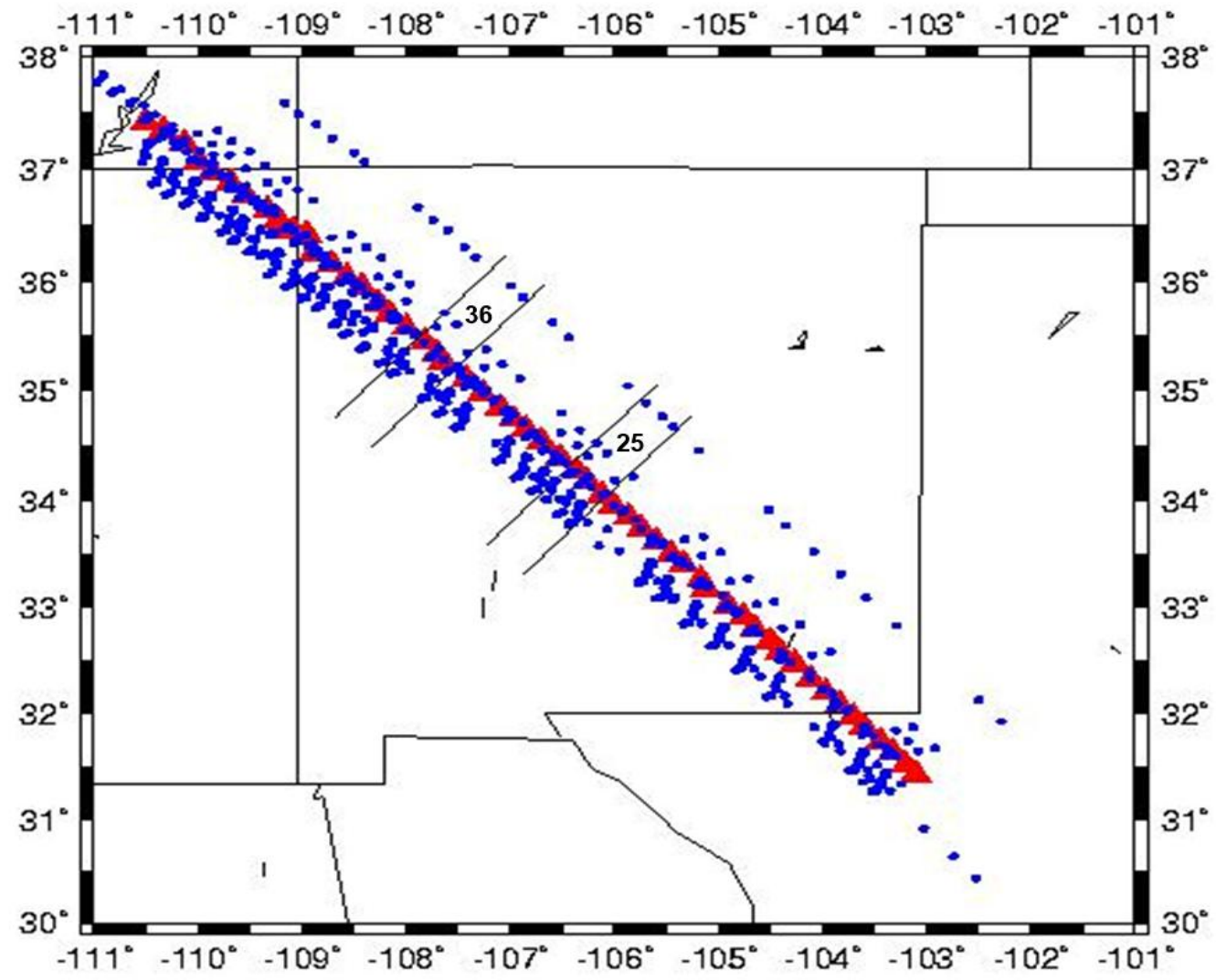

Figure 3. Configuration of bins of common conversion piercing points used in stacking receiver functions. The piecing points (blue dots) are calculated at a depth of $90 \mathrm{~km}$. Red triangles are stations and also the centers of each bin. Lines that are $44 \mathrm{~km}$ apart and perpendicular to the array show two bins centered at station 25 and 36, respectively. 

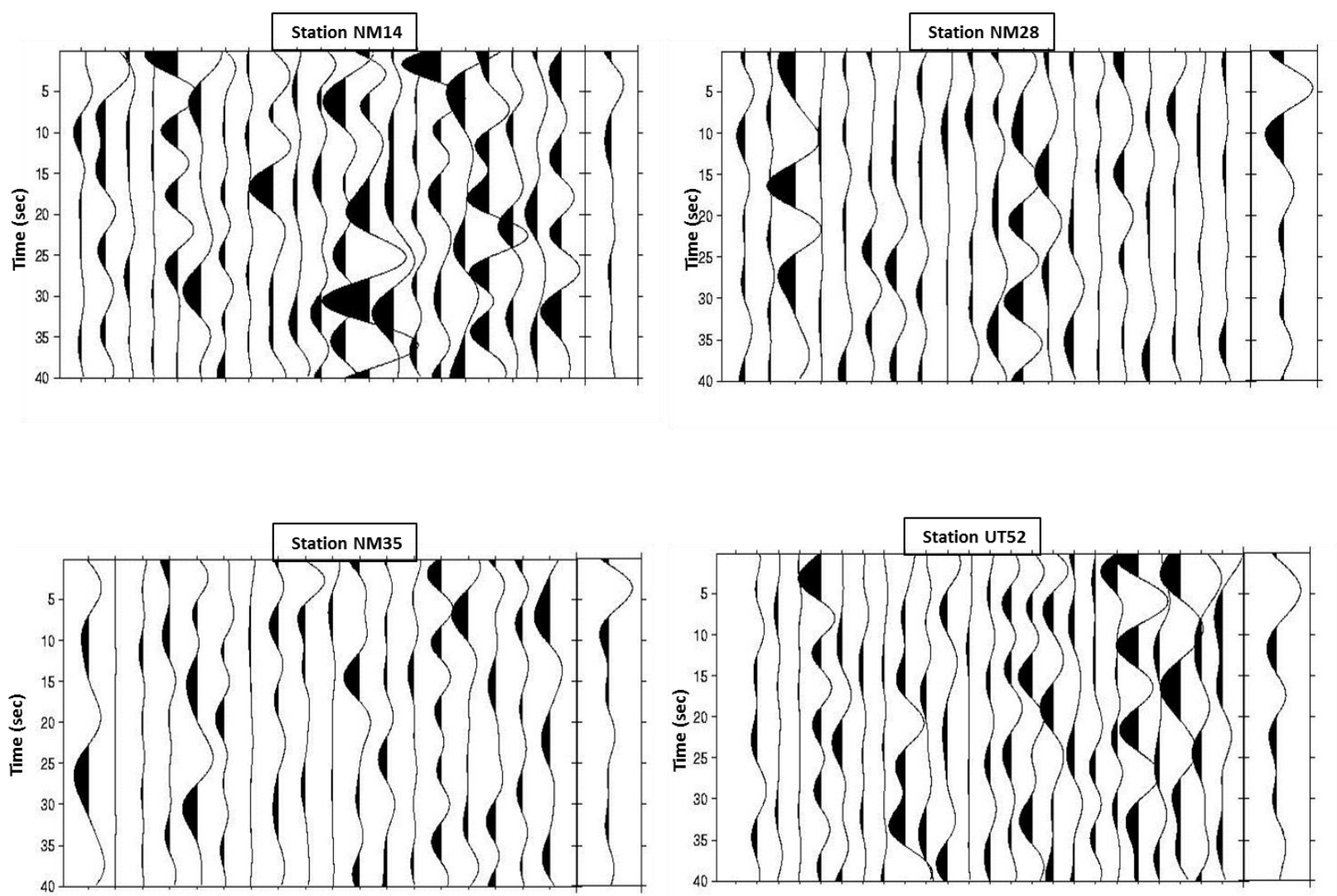

Figure 4. Individual receiver functions and their CCP stacks (the most right trace) at four bins centered at station NM14, NM28, NM35, and UT52, which are marked as black triangles in Fig 1. Negative amplitudes are filled with black. 


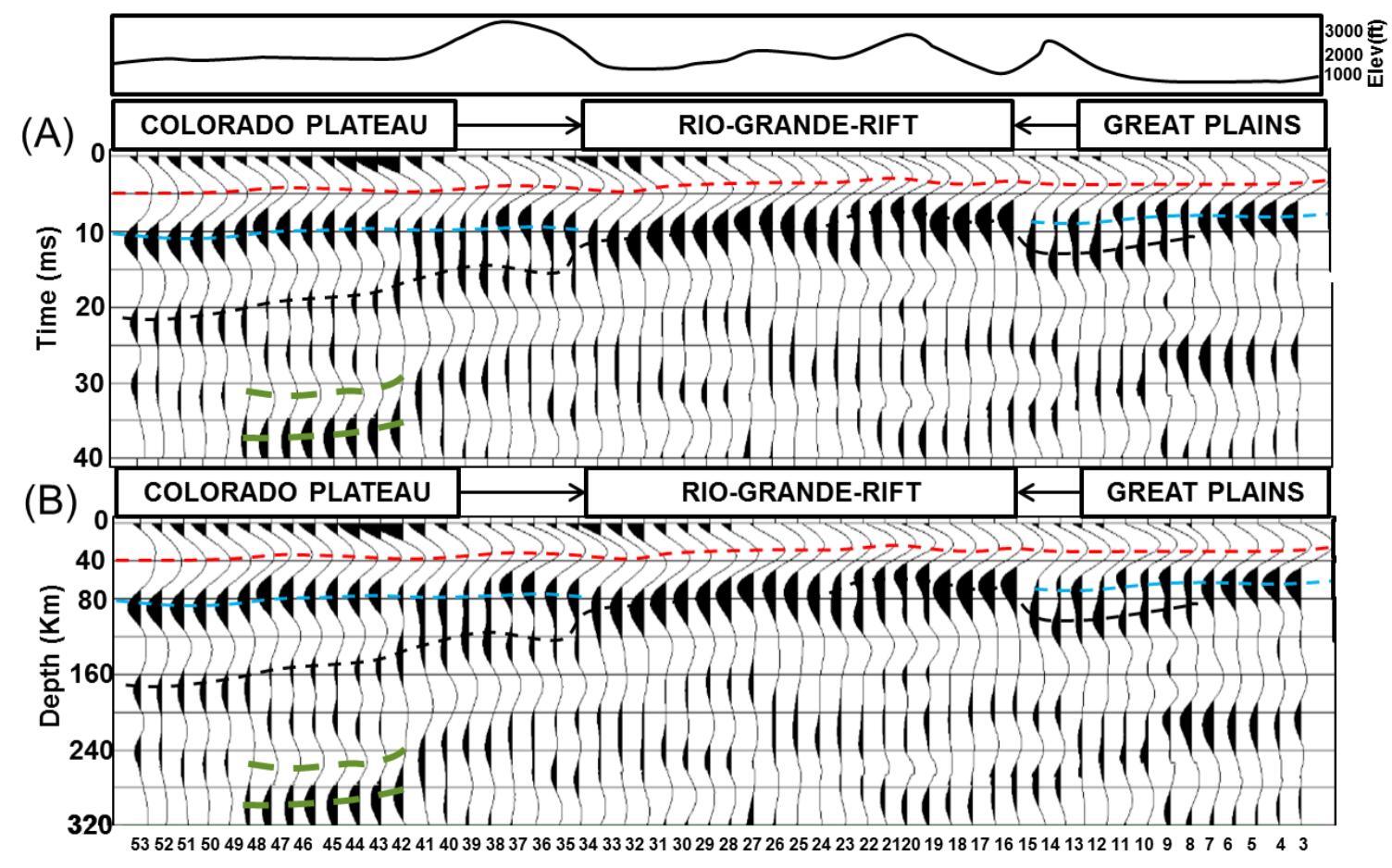

Figure 5. Profiles for $\mathrm{S}$ receiver function stacks at bins centered at each station. (A) Stacks of receiver functions in time. (B) Stacks converted to depth using the IASP91 model. The topography is plotted at the top to show tectonic provinces. Coherent phases are highlighted by dashed lines. Red dashed lines represent a positive phase from the Moho; black dashed lines represent a negative phase from the LAB; light blue dashed lines are largely side-lobes of the Moho conversion beneath the CP and GP or phases from a mid-lithosphere discontinuity. The green dashed lines mark local discontinuities with a positive and negative velocity gradient, respectively, probably the top and bottom of the eroded lithosphere. 


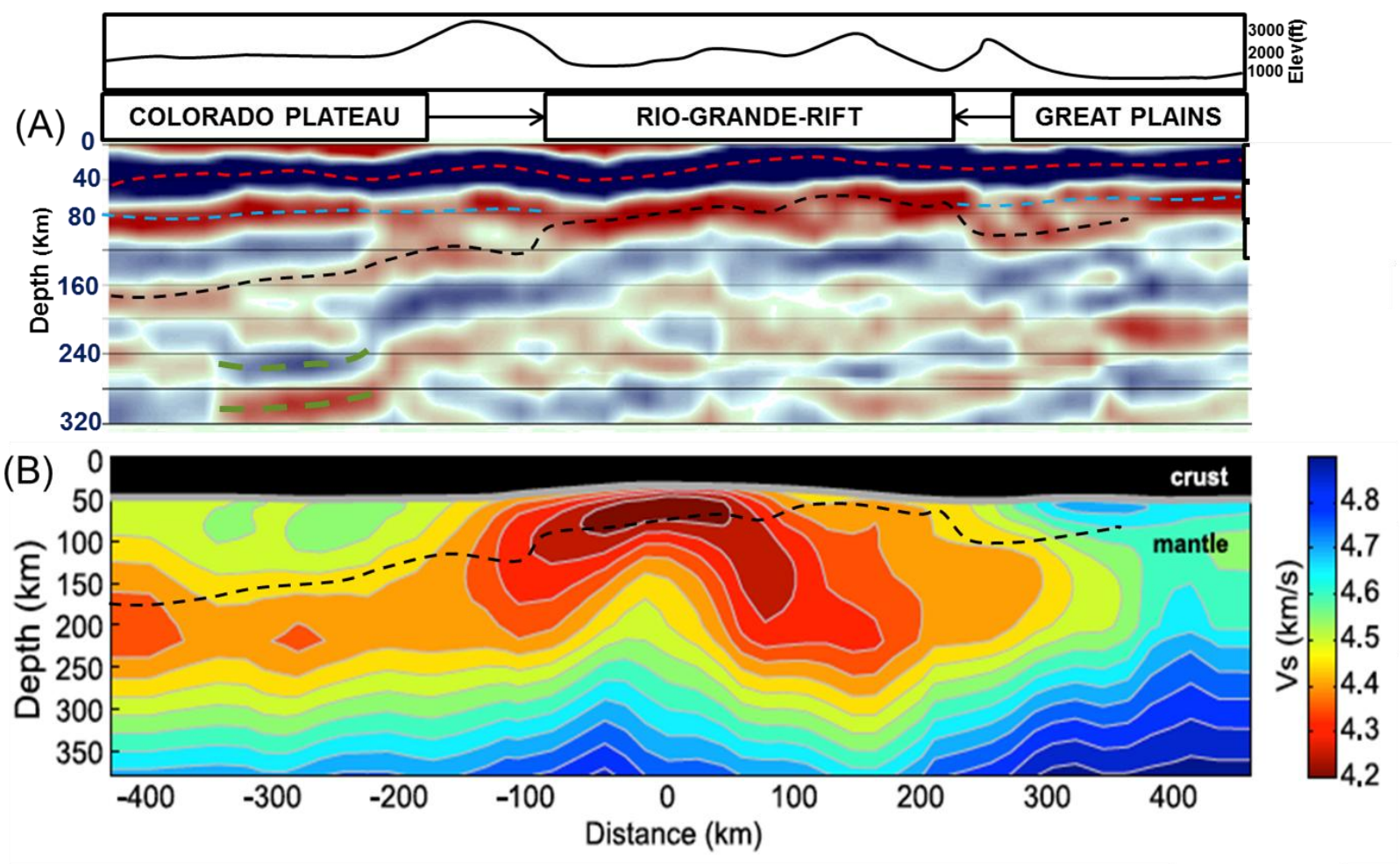

Figure 6: (A) Same as Fig. 5b with color-coded amplitude. (B) Shear wave velocity model beneath the RISTRA transect constrained from surface waves (West et al., 2004). Black dashed line is the LAB from $(\mathrm{A})$. 


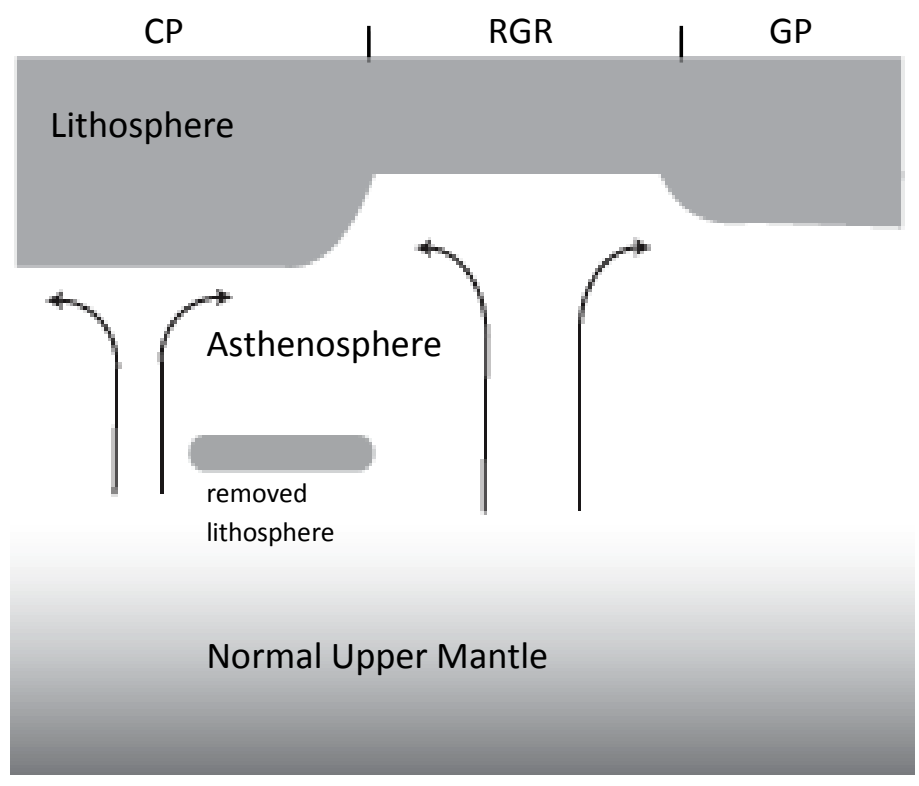

Figure 7. Schematic illustration for present day mantle dynamics beneath the Colorado Plateau, Rio Grande Rift, and Great Plains based on S-receiver function images in this study. 